\title{
Changing Demographics in Election Administration
}

\author{
Shauna Dozier
}

Abstract Over the last 15-20 years, the election administration profession has emerged from its status as an understudied area of public administration. At the same time, there has also been a demographic, cultural, and generational shift among election administration professionals. While some have embraced the shift, others have been resistant resulting in the exposure of beliefs and behaviors that are ageist, sexist, and racist. This case presents the experience of a 17-year career professional in the field who is both a woman and African American. Discussed here are both the mentorship and professional development training opportunities which have helped her navigate the field and the barriers and challenges that she continues to face as an election administration professional.

Keywords Mentorship $\bullet$ Professionalism $\bullet$ Diversity $\bullet$ Outreach

\footnotetext{
S. Dozier $(\bowtie)$

Clayton County, Georgia Board of Elections and Registration, Jonesboro, GA, USA e-mail: Shauna.Dozier@claytoncountyga.gov

(C) The Author(s) 2019

M. Brown et al. (eds.), The Future of Election Administration, Elections, Voting, Technology, https://doi.org/10.1007/978-3-030-18541-1_9
} 
My experiences come from an array of local jurisdictions, people, and situations. I have served as an election administrator in one of the smallest jurisdictions and the largest jurisdiction in Georgia. Throughout the evolution of my career as an election administrator, I received an education that is not necessarily taught in a classroom. The experiences highlighted in this case study are a compilation of a series of situations that I have experienced as an election administrator for over 15 years.

Currently, I serve as the Election Director at the Clayton County, Georgia Board of Elections and Registration located in Jonesboro, Georgia. Clayton County is a metro Atlanta County located 20 miles south of Atlanta, Georgia. Clayton County houses one of the world's busiest airports, the Hartsfield-Jackson Airport. Clayton County is also home of the Gone with the Wind movie (celebrating its 80th anniversary in 2019). Clayton County has over 191,000 registered voters with 58 polling locations and a population of 285,153 . The difference between the number of registered voters and the Voting Age Population is currently less than 12 percent.

Election administration was not my intentional career path, but unknowingly it became my professional future when I was a college student. As I entered this profession, I quickly found myself in the minority. I started as an election professional in my early 20s. I began my tenure serving as a precinct judge for the Durham County, North Carolina Board of Elections as a college student. I served while pursuing a degree in political science at North Carolina Central University (NCCU). As I attended poll worker training and assisted in serving voters, I began to wonder how one get involves in setting up elections. What are the criteria? Is there an educational track that can be used to get into a career in elections? I did not know where to start. Additionally, because historically and in my experience, election administrators and registrars were white, and were from 50 to 80 years old, I wasn't sure if there was room for me in this profession.

After I graduated from college, I relocated to Atlanta, Georgia. After a series of internship opportunities, I accepted an internship in the Georgia Secretary of State Elections Division. I served as an election intern for eight months which lead to my first full-time position as the Regional Voter Education Coordinator. As the coordinator, I served 53 counties in Northwest Georgia, under the State Elections Division in the Georgia Secretary of State Office. I conducted voter registration drives, coordinated 
voter education programs, conducted high school as well as university elections, and served as an Elections Monitor. I served as a Regional Voter Education Coordinator for a year. While in this role, one of my most memorable race-related experiences as an election administrator occurred about 20 miles outside of Atlanta, Georgia.

While in Haralson County, Georgia, I engaged in a conversation with a local resident who served as the president of the Historical Society. He was recruiting members to be a part of the Historical Society at the local library. I had a scheduled meeting with the Probate Judge but I arrived earlier than expected and decided to visit the library to provide voter registration applications and materials for patrons. Although I was discussing the Voter Education Program, the local was only interested in me becoming a member of the Historical Society to offer my family's history. I informed the local that I was not from the area but told him I would be open to meeting with the organization to promote voter registration.

The local then became combative and stressed the need for me to join the Society and provided his case for my ancestry. He believed I was the great-granddaughter of his grandmother's housekeeper. He assured himself that he was correct by stating I looked just like his grandmother's housekeeper. I further reminded the local that I do not have any ancestors in Haralson County, Georgia, provided him my card, and told him that if he was interested in voter registration to give me a call. The local then proceeded to give me directions on avoiding the highways to dodge the traffic going back to Atlanta. I respectfully accepted his directions and used my own.

Through my travel around the state, I met most of the election administrators in Georgia. But one meeting in particular changed my professional life. I randomly stopped in the Rockdale County, Georgia Board of Elections and Voter Registration Office to introduce myself and offered the state's voter education services. Rockdale County is located 25 miles east of Atlanta. It is the second smallest county in Georgia by area and at the time served about 55,000 registered voters. Shortly after the meeting, a job notice was advertised for the Assistant Supervisor of Elections in Rockdale. After a year of service in the State Elections Division, I accepted my first local election management position in the Rockdale County Board of Elections and Voter Registration Office in Conyers, Georgia.

After only being an employee of the county for a few short months, my first elections were during the 2008 presidential election cycle. Leading 
into the elections, I was provided training that taught me how to manage the day-to-day operations of elections and voter registration. The Supervisor of Elections, Cynthia Willingham, was responsible for my election administration development at the county level. She ensured that I was capable of management and made sure that I was properly trained using a hands on approach. This was different from the primary training method in election administration which some may refer to as baptism by fire. Her approach required long hours of oversight, shadowing, and reading the Georgia Elections Code page by page on a daily basis. I served as the Assistant Supervisor of Elections for 3.5 years.

After several years in the office, Cynthia felt that I was prepared for more responsibility and helped me transition into a position that would not only provide me with more responsibility but also more exposure. I accepted a position as the Administrative Coordinator of Elections (ACE) at the Fulton County Board of Registration and Elections in Atlanta, Georgia. ${ }^{1}$ Fulton County is the largest jurisdiction in Georgia with over 774,000 registered voters. The Deputy Elections Chief is responsible for election coordination in the county, serving as the direct report to the Elections Chief. This includes managing advance voting, ${ }^{2}$ poll worker recruitment, the maintenance as well as preparation of voting equipment, and changes in polling locations. During my tenure, I was exposed to a vast number of elections as well as voter registration situations. Some of my most notable experiences provided me with the opportunity to work with international elections. I served as a Facilitator for the Senegal presidential election held in Atlanta and I was appointed to serve as a Short Term Elections Observer for the 2015 early presidential election where I served in the Merki District of Kazakhstan. Based on the election and registration experience I received from previous employment, I also had the opportunity to serve in a dual management capacity in Fulton on a temporary basis.

I was appointed as the Interim Registration Chief and maintained my role as the ACE until I was hired as Registration Chief. I served in the Fulton County Board of Registration and Elections Office for five years, until I was hired in my current role as the Elections Director for the Clayton County Board of Registration and Elections during the 2016 presidential election cycle.

\footnotetext{
${ }^{1}$ This position is now referred to as the Deputy Elections Chief.

${ }^{2}$ Referred to as early voting in other jurisdictions.
} 
Throughout my career, in addition to challenges related to my race, I have also faced barriers as a professional in election administration related to my age. The challenge of managing a multigenerational workforce adds additional obstacles. Throughout my career, I typically have subordinates who range in age between 16 and 75 plus years old. When introducing myself, I receive the same question and response when I initially meet with my subordinates, "How old are you?" Although I do not provide a definitive answer, by veterans and baby boomers I'm often told, "You look young enough to be my daughter/granddaughter." This remark is occasionally followed by a pat on the head.

In most of the offices where I have worked, staffers who have worked in the office prior to my leadership appear to be reluctant to change. For example, increasingly when questioned about a process, the response from the more senior staff has been, "It has always been done this way." To the contrary, millennials may offer an easier way to complete a task using advanced software. That said, there is an advantage to managing a multigenerational workforce. Veterans, Baby Boomers, Generation X, Millennials, and Generation $\mathrm{Z}$ employees all offer experiences and skill sets that enhance the productivity of election administration when they embrace their roles in the office and jurisdiction. To bridge the gap, what has worked for me as a best practice has been to team the generations to work on projects together. This allows each group to learn from one another based on their experiences. This practice has yielded an increase in professional development and productivity among both groups involved.

In addition to challenges in the workplace, there have been times where my age has interfered with opportunities for professional growth. For example, in my late 20s, I applied for two election administration deputy positions in California. For one of the positions, I was one of six applicants that were flown to California for a two-part interview. I was in competition with other election directors including a former Secretary of State. I did not make it past the first round of interviews. I contacted the county's Human Resources Department to seek advice on how to improve my interview skills and to inquire about why I was not selected for the second round of interviews. The Human Resources Coordinator subtly told me that the panel was interested in someone who was more "settled" in their personal life. I begin to inquire about what that meant. She further 
explained to me that a young woman, single, and without kids presents a high risk of turnover. The county was not willing to take the risk.

The second position was an interview for the Assistant Registrar of Voters in a southern California County. I addition to participating in a WebEx interview, I also submitted responses to interview scenarios that would allow the panel to understand how I would manage election related situations. The panel and the then Registrar of Voters were impressed by my resume, experience, and how I responded to the interview questions. After several reference checks, I was offered the position verbally. Two days after the verbal offer, Human Resources informed me that the Registrar of Voters eliminated the position because she was appointed and was afraid that I would run against her for her position as a younger candidate. I was not aware that running for the position was an option at that time.

At one point, I applied for a Director of Elections position within a county office in which I worked at the time. After submitting my application and moving to the list of qualified candidates, I was directly approached by the then Registration Chief (who served as the Interim Director) and questioned about being qualified for the position. She appeared to be shocked and chuckled as she told me what I already knew, that I was qualified for the position. While looking for opportunities to advance professionally, I also began to pursue election administration specific certifications. I was not supported in this endeavor by the Registration Chief (Interim Director). I relied on my personal finances and family support to complete the majority of the Certified Elections Registration Administrator (CERA) certification classes and travel expenses. During this time, I was fortunate to have the professional support of the Elections Chief Dwight Brower, and when Rick Barron became the new Director of Elections in Fulton County, I was provided with financial support to finish my CERA courses. Like Cynthia, Dwight and Rick encouraged me to continue pursuing my education, learn as much as I could, and continue to apply for positions of more responsibility. Following their advice, I applied for a position as an Elections Director in a metro Atlanta county. After my interview, not being the selected for the position was yet again explained as there being concerns about my age, or being "settled." The focus was not on my experience or my ability to serve in the role of an Election Director. As we think about ways to grow the field and support the careers of women and young professionals, my recommendation to interview panelists and human resources professionals is to place emphasis on the professional experience of an applicant not their ability to grow a family. 
Election administration affords public servants an opportunity to serve the community. However, there are times when election officials have to face the sociopolitical aspects of customer service. For example, during an election a 75-year-old white male voter arrived in the office to submit an absentee ballot for another voter who did not meet the criteria of submission. The voter was informed of this and provided the statute from the Georgia Election Code. In response, the voter asked if the situation would be escalated to the director.

The staff called me to further assist the voter. I approached the voter and asked him how I could help him. He responded to me, "You can help me by getting the director." I informed the voter that I was the director and would be happy to assist him in this situation. He was given a copy of the Georgia Election Code and provided instructions on how to handle the ballot properly. The voter became infuriated and responded, "I will be glad when Barack Obama is out of office, that way we can get people like you out of this office and you will no longer have a job." The voter demanded to speak to the "white man in charge" (Prior to 2003, the role of Registrar was filled by a former Probate Judge). After again informing the voter that I was the director, he stormed out and screamed obscenities about me. Nothing could have prepared me for this experience because I realized this was another situation that was not about my ability. My lesson to constituents would be to be more open-minded about being assisted by someone who does not look like you.

Among my friends and family, I am the only person that serves in election administration. When I inform people of my job responsibilities, I receive the same question, "What do you do after Election Day?" Others feel compelled to further the conversation discussing politics and I feel compelled to provide a lesson on elections. Although I have and will continue to face challenges as an election professional, the connections I have made through my international observation missions, my experience working under individuals with an extensive knowledge of elections (averaging at least 25 years of elections experience), and formal training and networking through the completion of election administration courses through the Election Center and Auburn University have positioned me to be a better election professional. Additionally, because of this I am also able to ensure that those who I supervise are able to learn from the challenges I have experienced and have access to a network of working professionals that they can utilize as they navigate the profession. 
Moving forward it is important for those who are interested in the profession of election administration to continue professional development, embrace technology, prepare for high levels of scrutiny as we reach a new level of scholarship in the discipline of election administration, and be prepared to be more engaging with a multigenerational and multicultural voting age community. It is equally as important to mentor, cross-train staff, and strengthen voter education outreach through a multigenerational paradigm.

Open Access This chapter is licensed under the terms of the Creative Commons Attribution 4.0 International License (http://creativecommons.org/licenses/ by $/ 4.0 /)$, which permits use, sharing, adaptation, distribution and reproduction in any medium or format, as long as you give appropriate credit to the original author(s) and the source, provide a link to the Creative Commons licence and indicate if changes were made.

The images or other third party material in this chapter are included in the chapter's Creative Commons licence, unless indicated otherwise in a credit line to the material. If material is not included in the chapter's Creative Commons licence and your intended use is not permitted by statutory regulation or exceeds the permitted use, you will need to obtain permission directly from the copyright holder.

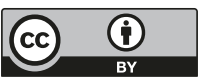

